\title{
STUDI FENOMENOLOGI TERHADAP WABAH KASUS SAKIT JIWA PADA WARGA DESA PANGAUBAN KABUPATEN BANDUNG
}

\author{
Siti Nurbayani ${ }^{1}$, Elly Malihah², Mirna Nur Alia ${ }^{3}$ \\ ${ }^{1}$ Dosen Program Studi Pendidikan Sosiologi \\ 2Dosen Program Studi Pendidikan Sosiologi \\ ${ }^{3}$ Dosen Program Studi Pendidikan Sosiologi
}

\begin{abstract}
ABSTRAK
Globalisasi adalah hal yang tidak mungkin dapat dihindari. Kesiapan serta bekal diri dalam menghadapinya merupakan hal yang wajib dimiliki manusia. Kompetisi aktif akan dihasilkan oleh pribadi yang siap, sebaliknya tekanan psikis seperti stress hingga sakit jiwa terjadi akibat dari ketidakmampuan dalam menghadapi globalisasi. Dibutuhkan bekal dalam menghadapi globalisasi melalui pendidikan keluarga, sekolah hingga masyarakat.
\end{abstract}

Kata kunci : globalisasi, gangguan psikis

\section{A. PENDAHULUAN}

Globalisasi membawa dampak semakin ketatnya persaingan hidup. Masyarakat dituntut untuk meningkatkan kualitas diri secara terus menerus sebagai upaya untuk mengimbangi globalisasi yang terjadi. Kualitas diri ini termanifestasi bukan hanya dalam bidang pendidikan tetapi juga pada bidang keterampilan individu itu sendiri. Kualitas diri juga dapat terbentuk melalui perjalanan hidup dengan segala pemaknaan terhadap kondisi yang terjadi, termasuk terhadap globalisasi beserta dampak-dampak pengiringnya. Individu yang tangguh secara mental dan fisik jelas sangat dibutuhkan pada era globalisasi. Permasalahannya sekarang adalah, sudahkah kita siap untuk berkompetisi?

Kompetisi dan aktualisasi diri dalam era globalisasi tentu bukan hal yang mudah. Hal ini tercermin dalam sebuah berita di "Pikiran Rakyat", tanggal 10 Februari 2014 yang menyebutkan bahwa terdapat 23 warga desa Pangauban, Kabupaten Bandung Barat mengalami sakit jiwa. Desa Pangauban ini diproyeksikan menjadi percontohan Desa Siaga Pelayanan Kesehatan Masyarakat (Yankes). Faktor keturunan memegang kunci penting dalam masalah gangguan kejiwaan. Sekalipun kadang individu tersebut terlihat normal, namun pada satu ketika mengalami sakit, stres, dan depresi, yang bisa menjadi pemicu sakit jiwa.

Data dari
Kabupaten
gangungkapkan bahwa penderita
Banguan jiwa baru di Kabupaten
diungkap Barat (KBB) yang berhasil
sebanyak 813 kasus.Kasus baru itu
terbagi dalam 72 orang mengalami
psikosis, neurosis (116 orang), NAPZA


(20), retardasi mental (7), dan gangguan jiwa lainnya (554).

Istilah gangguan mental (mental disorder) atau gangguan jiwa merupakan istilah resmi yang digunakan dalam PPDGJ (Pedoman Penggolongan Diagnostik Gangguan Jiwa). Definisi gangguan mental (mental disorder) dalam PPDGJ II yang merujuk pada DSM-III adalah:

"Gangguan mental (mental disorder) atau gangguan jiwa adalah sindrom atau pola perilaku, atau psikologik seseorang, yang secara klinik cukup bermakna, dan secara khas berkaitan dengan suatu gejala penderitaan (distress) atau hendaya (impairment/disability) di dalam satu atau lebih fungsi yang penting dari manusia.Sebagai tambahan, disimpulkan bahwa disfungsi itu adalah disfungsi dalam segi perilaku, psikologik, atau biologik, dan gangguan itu tidak semata-mata terletak di dalam hubungan orang dengan masyarakat". (Maslim, tth:7).

Sedangkan secara umum sehat mental dapat diartikan sebagai kondisi mental yang tumbuh dan didasari motivasi yang kuat ingin meraih kualitas diri yang lebih baik, baik dalam lingkungan keluarga, kehidupan kerja/profesi, maupun sisi kehidupan lainnya. Orang disebut memiliki mental yang tidak sehat ialah orang yang meskipun secara potensial memiliki kemampuan, tetapi tidak punya keinginan dan usaha mengaktualisasikan potensinya secara optimal (Wiramihardja, 2004, hlm. 23).

Kehidupan bermasyarakat tidak dapat lepas dari keberadaan empati.
Kohut (dalam Taufik, 2012, hlm 40) menyatakan empati "sebagai proses dimana seseorang berfikir mengenai kondisi orang lain yang seakan-akan dia berada pada posisi orang lain itu".

Pembentukan jati diri individu tidak lepas dari keluarga. Menurut Goode (2007, hlm. 16) bahwa :

Keluarga adalah satu-satunya lembaga sosial yang diberi tanggung jawab untuk mengubah suatu organisme biologis menjadi manusia. Pada saat sebuah lembaga mulai membentuk kepribadian seseorang dalam hal-hal penting, keluarganya tentu banyak berperan dalam persoalan itu, dengan mengajarinya kemampuan berbicara dan menjelaskan banyak fungsi sosial.

Pembentukan jati diri individu bukan hanya melalui keluarga, pendidikan juga ikut berperan penting, karena pendidikan merupakan suatu dasar pembentukan pola pikir, pola perilaku yang dapat diajarkan pada anak dengan memberikan bimbingan baik secara langsung maupun tidak. Menurut Ahmadi dan Uhbiyati, 2003, hlm. 69) menyebutkan : " Secara etimologis paedagogie berasal dari bahasa Yunani terdiri atas kata "PAIS" artinya anak, dam "AGAIN" yang artinya membimbing, jadi secara bahasa paedagogie yaitu bimbingan yang diberikan kepada anak.

Pola pengasuhan anak menjadi faktor utama bagi tumbuh dan kembang anak untuk mempersiapkan dirinya memasuki lingkungan masyarakat. Pola pengasuhan dalam penelitian ini bagaimana kesalahan 
pola asuh keluarga yang mengakibatkan anaknya mengalami gangguan jiwa.

Selain sebagai interaksi dan pembinaan terhadap pola asuh juga merupakan sekumpulan kebiasaan orang tua yang kemudian akan di identifikasi oleh anak untuk senantiasa mengikuti perilaku kedua orang tuanya. Menurut pendapat Slicker (dalam Rahayu dkk, 2008, hlm.64) bahwa "Pola asuh merupakan sekumpulan sikap, kebiasaan, dan ekspresi non verbal orang tua yang memberi ciri pada sifat interaksi anak dan orang tua dalam menghadapi berbagai situasi."

\section{FAKTOR}

YANG

MELATARBELAKANGI GANGGUAN JIWA PADA MASYARAKAT DESA PANGAUBAN

Menurut AN (39), sebagian besar warga yang sakit jiwa berasal dari kalangan bawah jika dilihat dari segi ekonomi dan umumnya mereka juga memiliki latar belakang pendidikan yang rendah. Usia mereka beragam mulai dari remaja hingga lansia yang tersebar hampir di seluruh wilayah Desa Pangauban kecuali RW 1 dan RW 13. Mengenai penyebab sakit jiwa yang menimpa warganya, AN menuturkan bahwa sakit jiwa yang dialami oleh warganya disebabkan oleh berbagai macam faktor yaitu depresi karena kehilangan harta benda, depresi karena perceraian, depresi karena kehilangan anggota keluarga, kehilangan rasa percaya diri karena kekurangan yang bersifat jasmaniah, tidak mampu memenuhi kebutuhan ekonomi, kerusakan sistem syaraf karena kecelakaan akibat kegagalan dalam tindakan medis dan ada pula yang disebabkan oleh kerusakan sistem syaraf akibat mengkonsumsi obat-obatan terlarang. Jika ditinjau dari sudut pandang kepribadian dan kehidupan sosialnya, mereka yang mengalami sakit jiwa pada umumnya beperilaku dan hidup wajar sebagaimana masyarakat desa pada umumnya yang lekat dengan nuansa kekerabatan dan gotong royong, namun menurut $\mathrm{AN}$ ada pula beberapa dari mereka yang sakit jiwa memiliki latar belakang kepribadian yang tertutup.

Selanjutnya, AE (56) ketua RW 12 yang merangkap kepala daerah (kader) desa siaga sehat jiwa Pangauban menuturkan bahwa di wilayahnya terdapat delapan orang yang menderita sakit jiwa. Beliau menyatakan bahwa latar belakang delapan pasien gangguan jiwa di RW 12 disebabkan oleh kondisi ekonomi keluarga yang berkekurangan.

\section{LATAR BELAKANG KELUARGA YANG MENGALAMI GANGGUAN JIWA}

Keluarga mempunyai andil terhadap derajat sehat dan sakitnya seseorang. Kondisi kehidupan keluarga merupakan stimulus internal sekaligus eksternal dalam mempercepat atau bahkan mengantisipasi munculnya berbagai gejala penyakit, dalam hal ini penyakit kejiwaan. Pada penelitian ini singgungan keluarga difokuskan pada peran keluarga sebelum dan sesudah pasien tersebut mengalami gangguan jiwa. 


\section{ANALISIS}

Penyebab seseorang sakit jiwa sangat bervariasi. Kondisi kejiwaan yang dalam bahasa Inggris disebut madness, merupakan bentuk ketidaknormalan otak dalam bekerja, sehingga penderita tidak menyadari apa yang dilakukannya. Penderita sudah tidak mengindahkan normanorma yang selalu diikuti oleh orang dalam keadaan normal.

Orang awam sering

mendefinisikan stress sebagai gangguan atau penyakit jiwa. Hal ini ternyata sama sekali tidak benar, perbedaan keduanya sangat banyak, oleh karena itu apa yang didefinisikan tersebut bahwa stress sama dengan sakit jiwa adalah salah.

Dalam forum FGD muncul
sebuah kesepahaman bahwa masyarakat harus dapat membedakan antara stress dan jiwa terlebih dahulu. Stress merupakan keadaan dimana orang terlalu terganggu oleh tekanan serta masalah hidup yang dihadapinya, sehingga mempengaruhinya secara psikologis. Stress yang tidak dikelola dengan baik, dan semakin bertambah parah, bisa menjurus kepada gangguan jiwa. Karena itu, masyarakat sebaiknya harus mulai dapat mengelola stress dengan benar. Dilihat dari jenisnya stress terbagi ke dalam dua jenis, yang pertama yaitu stress yang sifatnya positif atau eustress. Stress ini merupakan stress yang positif karena stress dengan jenis ini membuat orang yang mengalamiya terdorong dan termotivasi untuk melakukan sebuah tindakan atau usaha. Sedangkan yang kedua, yaitu stress yang sifatnya negatif atau distress. Stress jenis ini tingkatnya bisa tinggi ataupun rendah, namun tubuh menanggapinya dan bereaksi secara negatif dan cenderung merugikan dirinya.

Para ahli dalam FGD selanjutnya mengungkapkan ternyata stress bisa dialami oleh siapa saja, karena banyak faktor yang mempengaruhinya. Kebanyakan penyebab stress atau disebut juga stressor berasal dari luar seperti pekerjaan yang terlalu berat, pelajaran sekolah yang sulit, keadaan kesulitan ekonomi, ketidakharmonisan keluarga, serta hal hal lainnya yang membuat seseorang dalam kondisi tidak nyaman.

\section{PUSTAKA RUJUKAN}

Ahmadi, H.Abu dan Nur Uhbiyati. (2003). IImu Pendidikan. Jakarta : PT. Rineka Cipta.

Goode, (2007). Sosiologi Keluarga. Jakarta : Bumi Aksara.

Maslim, Rusdi. (2001). Diagnosis Gangguan Jiwa. Jakarta

Rahayu, S.Y., Hernawati, T., Rakhmawati, W.(2008). Hubungan Antara Pola Asuh Orang Tua (Parenting Style) Dengan Kesehatan Mental Remaja Di Ciawi Kabupaten Tasikmalaya. Jurnal Predicara. 1, (1), 21-36.

Wiramihardja, S.A. (2005). Pengantar Sosiologi Abnormal. Bandung: PT Refika Aditama

Taufik. (2012). Empati Pendekatan Psikologi Sosial. Jakarta: Raja Grafindo Persada. 